\title{
EUROPEAN UNION MECHANISMS FOR THE DEVELOPMENT OF THE TOURISM SECTOR IN RURAL AREAS*
}

\author{
Sinisa Domazet, Associate Professor ${ }^{1}$ \\ Jelena Jesic, Assistant Professor ${ }^{2}$ \\ Simonida Vukadinovic, Assistant Professor ${ }^{3}$ \\ DOI: https://doi.org/10.31410/tmt.2018.393
}

\begin{abstract}
The paper analyzes the mechanisms for the development of tourism in rural areas, especially the European Union state aid for rural development. This paper aims to underline the impact of social entrepreneurial system in the rural areas, that could benefit all stakeholders: tourists, business, local community and government with mutually beneficial situation of lowering the structural unemployment rate, returning young human capital to villages and innovating rural tourism through the activism of service science. Hence, the paper aims to point out the vital macroeconomic review of the Republic of Serbia, as a kind of indicators of the possibilities and conditions for the development of the right tools for employment in tourism sector in rural areas in Serbia. The research used normative methods, legal and logical methods of induction and deduction.
\end{abstract}

Keywords: Law, rural development, entrepreneurship, employment, sustainable development

\section{INTRODUCTION}

$\mathrm{R}$ ural tourism is defined as tourism that provides a „rural environment” to the visitor, offering him a combination of the experience of nature, culture and people of a typically authentic, original and fundamental experiences. Rural tourism returns visitors to nature, the roots, the basic one's things and supports return to origin and originality. Rural tourism includes a whole range of activities and services organized by the rural population.

It is based on sustainability principles and offers elements of a rural environment and nature, but also represents the traditional hospitality and living values of the local of the population. What makes rural tourism so unique is contact with this nature, as well as personal contact with local people. Rural accommodation combines different types of tourism that show rural life, art, culture and heritage in rural areas. World trends indicate that rural tourism becomes a wider concept, and that the needs and expectations of domestic and foreign demand of tourists become more sophisticated. Therefore, rural tourism is a combination of many different aspects experiencing, sharing and presenting rural life.

\footnotetext{
* This research is supported by the Ministry of Science and Technological Development of Serbia, as part of the projects: Interdisciplinary Research European integration and social and economic changes in Serbian economy on the way to EU [No. III 47009] and Basic Research Challenges and Prospects of structural changes in Serbia: strategic directions for economic development and harmonization with EU requirements [No. OI 179015].

1 University Educons, Vojvode Putnika 87, 21208 Sremska Kamenica, Serbia

2 University Educons, Vojvode Putnika 87, 21208 Sremska Kamenica, Serbia

3 University Educons, Vojvode Putnika 87, 21208 Sremska Kamenica, Serbia
} 
During the last decades, the tourism industry has increasingly been put side by side to development [1]. As in line with Moscardo [2] ,tourism is often proposed as a development strategy for rural regions based on assumptions made about the ability of tourists to generate employment and income for local residents and businesses".

But, for the development of tourism in rural areas it is necessary to apply different mechanisms. These mechanisms are, mainly, of an economic nature, but they also can be legal. Some of the mechanisms related to the various measures of stimulating employment, social entrepreneurship, as well as state aid measures of the European Union for the development of rural areas. The above-mentioned mechanisms would be of great importance for the development of entrepreneurship in rural areas in the Republic of Serbia.

\section{MACROECONOMIC REWIEV OF THE REPUBLIC OF SERBIA}

As a candidate country for entering the European Union from the year of 2013, The Republic of Serbia has not only received many economy benefits, but requests for fulfilling some obligations and recommendations as well.

\begin{tabular}{|c|c|c|c|c|c|c|c|c|c|c|c|}
\hline & 2007 & 2008 & 2009 & 2010 & 2011 & 2012 & 2013 & 2014 & 2015 & 2016 & 2017 \\
\hline Real GDP growth (in \%) ${ }^{1)}$ & & & & & & & & & & 3.3 & 2.0 \\
\hline $\begin{array}{l}\text { Consumer prices (in \%, } \\
\text { relative to the same month } \\
\text { a year earlier) }\end{array}$ & 11.0 & 8.6 & 6.6 & 10.3 & 7.0 & 12.2 & 2.2 & 1.7 & 1.5 & 1.6 & 3.0 \\
\hline $\begin{array}{l}\text { NBS foreign exchange } \\
\text { reserves (in EUR million) }\end{array}$ & 9,634 & 8,162 & 10,602 & 10,002 & 12,058 & 10,915 & 11,189 & 9,907 & 10,378 & 10,205 & 9,962 \\
\hline Exports (in EUR million) $\left.{ }^{3}\right)$ & 8,110 & 9,583 & 8,043 & 9,515 & 11,145 & 11,469 & 13,937 & 14,451 & 15,728 & 17,385 & 19,330 \\
\hline $\begin{array}{l}\text { - growth rate in } \% \\
\text { compared to a year earlier }\end{array}$ & - & 18.2 & -16.1 & 18.3 & 17.1 & 2.9 & 21.5 & 3.7 & 8.8 & 10.5 & 11.2 \\
\hline Imports (in EUR million) ${ }^{3)}$ & 15,468 & 18,267 & 13,099 & 14,244 & 16,487 & 16,992 & 17,782 & 18,096 & 18,643 & 19,597 & 22,365 \\
\hline $\begin{array}{l}\text { - growth rate in } \% \\
\text { compared to a year earlier }\end{array}$ & - & 18.1 & -28.3 & 8.7 & 15.7 & 3.1 & 4.7 & 1.8 & 3.0 & 5.1 & 14.1 \\
\hline $\begin{array}{l}\text { Current account balance } \\
\text { (in EUR million) }\end{array}$ & $-5,474$ & $-7,126$ & $-2,032$ & $-2,037$ & $-3,656$ & $-3,671$ & $-2,098$ & $-1,985$ & $-1,234$ & $-1,075$ & $-2,090$ \\
\hline as $\%$ of GDP & & & & & & & & & -3.5 & -2.9 & -5.2 \\
\hline $\begin{array}{l}\text { Unemployment according } \\
\text { to the Survey (in \%) }{ }^{7}\end{array}$ & 18.1 & 13.6 & 16.1 & 19.2 & 23.0 & 23.9 & 22.1 & $\left.19,2^{7}\right)$ & 17.7 & 15.3 & 13.5 \\
\hline $\begin{array}{l}\text { Wages (average for the } \\
\text { period, in EUR) }\end{array}$ & 347.1 & 402.0 & 337.8 & 331.8 & 372.5 & 366.1 & 388.5 & 379.8 & 367.9 & 374.5 & 383.9 \\
\hline $\begin{array}{l}\text { RS budget deficit / surplus } \\
(\text { in } \% \text { of GDP })^{4)}\end{array}$ & & & & & & & & & -2.7 & -0.2 & 0.7 \\
\hline $\begin{array}{l}\text { Consolidated fiscal result } \\
(\text { in } \% \text { of GDP) })^{4}\end{array}$ & & & & & & & & & -3.5 & -1.2 & 1.1 \\
\hline $\begin{array}{l}\text { RS public debt, (central } \\
\text { government, in \% of GDP) }{ }^{9}\end{array}$ & & & & & & & & & 70.0 & 67.8 & 57.9 \\
\hline $\begin{array}{l}\mathrm{RSD} / \text { EUR exchange rate } \\
\text { (period average) }\end{array}$ & 79.96 & 81.44 & 93.95 & 103.04 & 101.95 & 113.13 & 113.14 & 117.31 & 120.73 & 123.12 & 121.34 \\
\hline $\begin{array}{l}\text { MEMORANDUM: } \\
\text { GDP (in EUR million) }\end{array}$ & & & & & & & & & 35,716 & 36,723 & 39,183 \\
\hline
\end{tabular}

Table 1. Macroeconomic indicators of The Republic of Serbia, selected indicators 2008-2017. (Source: www.nbs.rs, on 08.11.2018.)

Table 1. [3] represents that GDP growth decreased (2\% in 2017 from 3,3\% in 2016), inflation rate was around 3\% and unemployment rate decreased from 2016 to 2017 year (13.5\% in 2017 from 
15,3 in 2016), as three most important indicators. Public dept was 57,9\% of GDP, and balance of payment is negative for the all the period of ten years. Serbia still imports more than the country exports.

One of recommendations given to Serbia in Strategy 2020 is reaching employment rate of 65\%.

\begin{tabular}{lr} 
EU-28 & 71.1 \\
\hline Albania $\left({ }^{(}\right)$ & 62.1 \\
\hline Serbia & 59.1 \\
\hline Montenegro & 57.1 \\
\hline Turkey & 54.3 \\
\hline FYR Macedonia & 53.3 \\
\hline Bosnia and Herzegovina & 44.2
\end{tabular}

Note: ranked on the total employment rate (male and female).

(1) Estimates.

Table 2: Employment rates (persons aged 20-64), 2016 (\% of labour force)

Source: Eurostat (online data code: lfsi_emp_a)

https://ec.europa.eu/eurostat/statistics-explained/index.php/Enlargement_countries_-_labour_ market_statistics\#Employment_rates

As it is presented in the Table 2 [4] Serbia had 59,1\% employment rate in the year of 2016.

It is not easy to reach 2020 recommendation, but the sectoral employment trends are in the line with EU28 trends, only sector of services is expanding by sectoral division. This is in line with potential of employment in the sector of rural tourism, and its development.

\begin{tabular}{|c|c|c|c|c|c|c|c|c|}
\hline & \multicolumn{2}{|c|}{$\begin{array}{l}\text { Agriculture, for- } \\
\text { estry and fishing }\end{array}$} & \multicolumn{2}{|c|}{ Industry } & \multicolumn{2}{|c|}{ Construction } & \multicolumn{2}{|c|}{ Services } \\
\hline & 2011 & 2016 & 2011 & 2016 & 2011 & 2016 & 2011 & 2016 \\
\hline EU-28 & 5.0 & 4.3 & 17.6 & 17.2 & 7.4 & 6.7 & 70.0 & 71.8 \\
\hline Montenegro & 5.6 & 7.7 & 13.0 & 9.8 & 6.0 & 7.7 & 75.5 & 74.8 \\
\hline FJR Macedonia (1) & 18.7 & 16.6 & 23.8 & 23.1 & 6.2 & 7.2 & 51.3 & 53.1 \\
\hline Albania & 45.4 & 40.2 & 10.6 & 12.8 & 8.2 & 6.5 & 35.8 & 40.5 \\
\hline Serbia $\left({ }^{2}\right)$ & 21.2 & 18.6 & 21.5 & 20.2 & 5.3 & 4.3 & 52.0 & 57.0 \\
\hline Turkey $\left({ }^{3}\right)$ & 25.5 & 19.5 & 19.5 & 19.5 & 7.0 & 7.3 & 48.1 & 53.7 \\
\hline Bosnia and Herzegovina( $\left(^{4}\right)$ & 20.6 & 18.0 & 21.5 & 22.7 & 8.9 & 8.6 & 49.1 & 50.8 \\
\hline
\end{tabular}

(1) 2011: low reliability.

$\left({ }^{2}\right)$ Break in series.

(3) 2011: agriculture, forestry and fishing include NACE Rev. 2 Group 98.1 (undifferentiated goods-producing activities of private households for own use).

Table 3. Employment by sectors EU28 and enlargement countries, (aged $15+$ ), as a $\%$ of total employment

Source: https://ec.europa.eu/eurostat/statistics-explained/index.php/Enlargement_countries_-_ labour_market_statistics\#Employment_rates

By the data of Statistical Office of the Republic of Serbia [5], estimated population of Serbia was $7,040,272$ in the beginning of 2017. The great problem of the country are emigrations, especially for the working reasons, and therefore the country is one of the world's leaders in the phenomena of brain drain. Authors of this paper try to find the solution for preventing this emigration process as well increasing employment rates in Serbia by keeping investing in rural tourism both by Serbian and EU funds' investments. 


\subsection{Employment in sector of rural development in Serbia}

Serbia's utilized agricultural area is 3.44[6] million ha (around 44\% of the country's territory), the Predominant land uses arable land (73\%) followed by permanent grassland and crops. According to the available data from 2012 (when inventory of agriculture was last time made from the Statistic office of Serbia), 55\% of the population of the Republic lives in rural areas, generating $41 \%$ of the country's GDP, the importance of rural development is undeniable. ,Small rural households are highly represented in the socioeconomic structure of rural households in Serbia. Households of up to 3 ha have about 328,000 and make up about $56 \%$ of all households in rural areas. Over 600,000 farms have less than 5 ha of land. The average size of the family farm in Serbia is about 3.7 ha. Private ownership is the dominant form in the ownership structure of 5.4 million hectares of the total agricultural land of Serbia. Of the total arable land, $83.7 \%$ are in private property. The agrarian population includes over 60 years of age with a lower level of education and a large percentage of dependents over the age of 15 years. Unemployment in rural areas reaches as much as $21 \%$, adding covert unemployment. Despite the exodus from rural areas, in Serbia the share of agriculture in employment remained among the highest in Europe, with $33 \%$ of employees in the primary sector, while $75-80 \%$ of active working population in rural areas involved in agriculture' [7].

The Strategy for Agriculture and Rural Development [8] of the Republic of Serbia for the period 2014-2020, emphasizes the potential of the rural tourism sector. The need for rural tourism sector development is stressed, but without the budget for these purposes, nor the guidelines in the further development of this sector. This document indicates a positive shift in the domain of defining the first outlines of rural development policy based on the EU model of support.

The Tourism Development Strategy of the Republic of Serbia [9] for the period from 2016 to 2025 , also highlights the great potential of rural tourism. It is mentioned in this document that in 2014, according to Eurostat, only 506 foreign tourists visited rural tourism facilities of Serbia. The strategy does not include data on rural tourism capacities. The necessity is emphasized in accordance with this Strategy and the Program for the Development of Sustainable Rural Tourism in the Republic of Serbia to support commercial training programs for rural farms interested in rural tourism, various models of partnerships with registered farms that will connect resources, knowledge and skills. Special attention should be paid to the possibility of using incentive programs for financing the development of rural tourism from the IPARD program of the EU, which envisages the use of about 18 million EUR for the development of rural tourism;

Strategic tourist markets for the tourism industry of Serbia include, among others, rural tourism. List of priority activities and programs that are financed and supported by the EU (under the count 16.18 and 22.) [10]:

1. Vocational training and skills acquisition (courses, workshops, for example how to develop rural tourism), as well as other information activities that help linking and sharing knowledge and experiences in tourism;

2. Support for start-ups and investments in non-agricultural activities in rural areas (rural accommodation, shops, restaurants, organization of tours, ...);

3. Establishment of cooperation involving at least two entities (creation of strategic business areas, cooperation between small operators in organizing the common labor market and use of facilities and funds for development and / or marketing of tourist services related to rural tourism and other related activities). 
Number of rural touristic destination as well as their facilities increases in Serbia year after year, but there is no statistic according to the number of them as well as there is no official data about number of people employed in this part of touristic supply, especially for a great number of people in rural areas having accommodation capacity for guests, that are working both in agriculture production and rural tourism as well.

It could be found on some internet portals which represent rural touristic destination - approximate number of households. In the beginning of 2018 year, there was more than 900 [11] rural households registered for work with tourists in Serbia. Among them, there are almost a hundred of those who yearn up to 1,300 people, so they are for that reason forced to stop completely in agriculture and turn to the hospitality industry. The majority of supply of the rural touristic destinations in Serbia could be found at portal https://www.selo.rs/rs [12].

Employment is one of the crucial economic factors for development of the country, and if all stakeholders in Serbia invest more in the agricultural sector (and thus in the rural tourism sector) we can find our economy increasing in all its fields [13].

\section{THE INCITEMENT OF SOCIAL ENTREPRENEURSHIP AS A TOOL FOR DEVELOPING TOURISM SECTOR IN RURAL AREAS}

Social entrepreneurship in the function of maximizing social values and state aid to the most vulnerable groups of society can lay the foundations of rural development in the long run. In the European Union, the concept of social entrepreneurship is present in the contemporary form since the 1980s, while the process of expanding this form of entrepreneurship is under way in the Republic of Serbia.

State aid for rural development can also be achieved in an indirect way by encouraging social entrepreneurship in rural areas. Unlike traditional entrepreneurship, where the primary goal of activity is the achievement and maximization of profit, in the focus of social entrepreneurship is the satisfaction of social needs. Due to the extremely pronounced social dimension, this type of entrepreneurship can be classified into models very close to the state's incentives for rural development [14]. Defining the notion of social entrepreneurship and social enterprise is not an easy task at all because there are no unique definitions, but there are some important and common characteristics that, as a common content, are found in all the definitions of social entrepreneurship. Therefore, social entrepreneurship can be presented as entrepreneurship with ethical integrity in order to maximize social value, not private value or profit. This means that earned assets do not serve to increase the assets of individuals - they are investing for purposes such as the employment of people who are striving to work, education, environmental protection, social and medical services, cultural activities in the community or other areas that in the first place give contribution to a better society. Social entrepreneurship is specific in that it deals with the identification and solution of social problems such as social exclusion, poverty, unemployment, and so on.

This is one of the reasons why social entrepreneurship can be a useful tool for the development of the tourism sector in rural areas, by creating socio-economic and socio-cultural changes in local communities. By focusing on socio-economic and socio-cultural changes, and social organizations (founded by a social entrepreneur(s)), it is being expressed how a social entrepreneur inscribes and takes advantage of the existing conditions of the world, hence sees and exploit an opportunity. This trend thus works in shaping and affecting how those organizations 
maintain their social framework from which they work to obtain their 'social mission'. Since the term social entrepreneur remains ,fluffy' defined and understood differently in literature [15] in this project, the definition of a social entrepreneur encompasses the qualities and behaviors associated with the business entrepreneurs, however working in a community to help and care rather than to make profit, which is being done through different venture aiming to impose a socio-economic change which will inherently strengthen individual wealth and adding value to the community [16]. As the Duke University's Fuqua School of Business, the Center for the Advancement of Social Entrepreneurship (CASE) writes: „social entrepreneurs are innovative, resourceful, and result-oriented, who draw upon the best thinking in both the business and nonprofit worlds to develop strategies that maximize social impact" (CASE cited in [17]).

The European Commission uses the concept of a social enterprise for the following types of business [14]:

1. those in which the social goal is the main reason for commercial activities and which often have a form of social innovation;

2. those whose profit is mostly reinvested in order to achieve the set social goals;

3. those in which the way of organizing and managing, and the rights of the owners reflect company missions, use democratic and participatory principles or principles of social justice.

Social enterprises have proved to be an innovative organizational form in the EU countries. They became even more capable than traditional non-profit organizations to respond to the evolution of demand for services of general interest, in particular demand from users whose services of general interest are less available. The idea of adopting entrepreneurial models for productive and service activities with pronounced social content, where the management of these new enterprises directly involves not only the workers, but also the civil society in general, proved to be successful. By launching the concept of social enterprises in the contemporary form, in the 1980s, the supply and efficiency in the sector of production and services improved in which the reliance on technological innovations, due to the limited availability of financial resources, was not possible [18].

The goal of studying and identifying examples of good practice in the field of social entrepreneurship, as well as new policies and measures that need to be applied, is that the benefits of growth and development must spread across all parts of society [19]. The Serbian government defined rural development in Serbia as economically, socially and ecologically priority. The diversification of the rural economy into a social, economic and environmentally sustainable way, is necessary in order to improve the quality of life, to reduce the level poverty, as well as the fight against social and environmental degradation.

The Serbian government defined rural development in Serbia as an economic, social and ecological priority. The diversification of the rural economy into social, economic and environmentally sustainable way, is necessary in order to improve the quality of life, to reduce the level of poverty, as well as to make the fight against social and environmental degradation more intensified.

Rural tourism is defined as tourism that provides a „rural environment” to the visitor, offering him a combination of the experience of nature, culture and people of a typically rural character. The essence of rural life makes the full enjoyment of the visitor into authentic, original and fundamental experiences. Rural tourism returns visitors to nature, the roots, the basic one's things and supports return to origin and originality. Rural tourism includes a whole range of activities and services organized by the rural population. 
It is based on sustainability principles and offers elements of a rural environment and nature, but also represents the traditional hospitality and living values of the local population. What makes rural tourism so unique is contact with this nature, as well as personal contact with local people. Rural accommodation combines different types of tourism that show rural life, art, culture and heritage in rural areas. Therefore, rural tourism is a combination of many different aspects experiencing, sharing and presenting rural life.

Rural development is one of the aspects of national planning which seeks to improve the quality of life of the local community in order to achieve sustainable development [19]. Rural development aims to improve livelihoods by implementing comprehensive development for rural areas where a majority of people in poverty live. Thus, it can also contribute to reduce poverty in urban areas by reducing excessive population influxes from rural areas [20]. Mukhtar [21] sees rural development as a process of bringing improvement in the living conditions of rural dwellers through employment of generations and entrepreneurship development in the rural area, while Jha and Jha [22] define rural development as the process of developing and utilizing natural human resources, technologies, infrastructure facilities, institutions and organizations to improve the quality of life in the rural areas.

The benefits of social enterprises for rural areas described are that, by using a bottom-up approach, services provided will more appropriately meet local needs and, by doing this, satisfy the distinctive needs of local communities [23]-[25]. Working collectively creates social capital and builds confidence that can be applied to other community issues [26]. Rural social enterprises are able to build human capacity i.e. 'cells of people' forming a lobby that put pressure on council officers and members to find ways of continuing to support socially orientated projects.

Additionally, in our work we seek to bring forth new perspectives on social entrepreneurship in relation to development as a consequence of tourism whereas it accordingly comprises the complexities within drawing usage of the tourism sector as engine for development in European Union, as well as Republic of Serbia, as a candidate country.

For example, LEADER [27] is one of the proven effective approaches to rural development based on the mobilization of one's own the potential of local communities for their development. The LEADER approach focuses on „HOW”, more than what „WHAT” needs to be done. In this sense, it involves the formation of multisectoral one's local partnerships, i.e. local action groups (LAGs) in a specific rural area with a unique identity. LAGs manage development in accordance with the specific needs of the local population / territory - through decision making, design of local rural development strategy (LSRR), allocation of financial resources and implementation projects. LEADER is not a new model of rural development, since it was introduced in the countries of the European Union (EU) for the first time in 1991, as The Community Initiative Program, funded by the Structural Funds, was intended innovative pilot projects that encourage rural development.

Since 2007, LEADER has become an integral part of the Rural Policy, i.e. the Common Agricultural Policy of the European Union (ZAP), with a total budget of 2.5-5\% (approximately 2.5-5 billion $€$ ) of the total resources of the European Agricultural Fund for rural development (EAFRD). LEADER has since become an integral part of the National Rural Development Programs of EU Member States, within which the LEADER stands out from 2.3-11.3\% of the funds. The implementation of Local Rural Development Strategies is in the 10th the most important measures of the European Agricultural Fund for Rural Development, for which 4\% of the total budget is allocated. 


\section{STATE AID TO RURAL AREAS IN THE EU}

One of the main legal and economic instruments for developing rural areas in the European Union is state aid. In general, state aid is not allowed according to the Treaty on the Functioning of the European Union (Articles 107-109). Article 107(1) of the Treaty on the Functioning of the European Union (further: TFEU) stipulates that, (s)ave as otherwise provided in the Treaties, any aid granted by a Member State or through State resources in any form whatsoever which distorts or threatens to distort competition by favouring certain under takings or the production of certain goods shall, in so far as it affects trade between Member States, be incompatible with the internal market. Application of the general State aid rules to the agricultural sector is limited by Article 42 of the Treaty on the Functioning of the European Union. According to that Article, the provisions of the Chapter relating to rules on competition shall apply to production of and trade in agricultural products only to the extent determined by the European Parliament and the Council within the framework of Article 43(2) and in accordance with the procedure laid down therein, account being taken of the objectives set out in Article 39.

So, from the above-mentioned prohibitions there are some exceptions, provided by the provisions of the TFEU. In terms of agriculture, we should mention the provisions of Art. 107 (2) (b) TFEU, where it is stated that the state aid to remove the damage caused by natural disasters or emergencies will be compatible with the internal market. It is similar with Article 107 (3) (c) TFEU, which states that the Commission can consider that state aid to promote the economic development of the agriculture and forestry and rural areas to be compatible with the internal market, if there are no adverse effects on trading conditions.

The allocation of state aid in the agriculture and forestry, as well as in rural areas in the Union is governed by the European Union Guidelines for State aid in the agricultural and forestry sectors and in rural areas 2014 to 2020 (further: Guidelines) [28].

In these Guidelines, the Commission sets out the conditions and criteria under which aid for the agricultural and forestry sectors and for rural areas will be considered to be compatible with the internal market and establishes the criteria for identifying the areas that fulfil the conditions of Article 107(3) of the Treaty. As regards aid granted pursuant to Article 107(2)(b), the Commission hereby sets out the conditions which will be verified in order to determine whether a measure constituting aid to make good the damage caused by natural disasters or exceptional occurrences is indeed covered by that Article [28]. The rural development policy 2014-2020 shall contribute to achieving the following objectives: (1) fostering the competitiveness of agriculture; (2) ensuring the sustainable management of natural resources, and climate action; and (3) achieving a balanced territorial development of rural economies and communities including the creation and maintenance of employment. The achievement of these objectives of rural development shall be pursued through the following Union priorities for rural development: (1) fostering knowledge transfer and innovation in agriculture, forestry, and rural areas; (2) enhancing farm viability and competitiveness of all types of agriculture in all regions and promoting innovative farm technologies and sustainable management of forests; (3) promoting food chain organization, including processing and marketing of agricultural products, animal welfare and risk management in agriculture; (4) restoring, preserving and enhancing ecosystems related to agriculture and forestry; (5) promoting resource efficiency and supporting the shift towards a low carbon and climate resilient economy in agriculture, food and forestry sectors; and (6) promoting social inclusion, poverty reduction and economic development in rural areas [28]. 
Common principles applicable to the assessment of the compatibility of aid measures implemented by the Commission are contained in the Communication on the modernization of state aid [29]. The Communication on State aid modernization called for the identification and definition of common principles applicable to the assessment of compatibility of all the aid measures is carried out by the Commission. For this purpose, the Commission will consider an aid measure compatible with the Treaty only if it satisfies each of the following criteria: a) contribution to a well-defined objective of common interest: a State aid measure must aim at an objective of common interest in accordance with Article 107(3) Treaty; b) need for State intervention: a State aid measure must be targeted towards a situation where aid can bring about a material improvement that the market cannot deliver itself, by remedying a well-defined market failure; c) appropriateness of the aid measure: the proposed aid measure must be an appropriate policy instrument to address the objective of common interest; d) incentive effect: the aid must change the behaviour of the undertaking(s) concerned in such a way that it engages in additional activity which it would not carry out without the aid or it would carry out in a restricted or different manner; e) proportionality of the aid (aid limited to the minimum necessary): the aid amount must be limited to the minimum needed to induce the activity in the sector concerned; f) avoidance of major undue negative effects on competition and trade between Member States: the negative effects of aid must be sufficiently limited, so that the overall balance of the measure is positive; g) transparency of aid: Member States, the Commission, economic operators, and the public must have easy access to all relevant acts and to pertinent information about the aid granted thereunder [28].

These Guidelines apply to State aid for the primary agricultural production, the processing of agricultural products resulting in another agricultural product and the marketing of agricultural products [28]. Also, in view of the aforementioned considerations, these Guidelines cover the following categories of aid: (a) measures in the agricultural sector, financed exclusively from national funds, which consist of: (i) rural development like measures falling outside the framework of a rural development programme; (ii) measures other than those referred to in (i) which fall outside the scope of Regulation (EU) No 1305/2013, such as certain risk and crisis management measures, aid for the livestock sector and certain promotion measures [28].

Where the conditions of Article 107(1) of the Treaty are met, Member States must notify to the Commission aid in the agricultural and forestry sectors and in rural areas pursuant to Article 108(3) of the Treaty and shall not put the proposed measure into effect until this procedure resulted in a final decision, with the exception of measures that fulfil the conditions laid down in a block exemption regulation [28].

The Guidelines provided a number of different categories of state aid:

1. Aid in favour of undertakings active in the primary production, processing and marketing of agricultural products:

a) Rural development measures (Aid for investment in tangible assets and intangible assets on agricultural holdings linked to primary agricultural production, Aid for investments in favour of the conservation of cultural and natural heritage located on agricultural holdings, Aid for investment concerning the relocation of farm buildings, Aid for investments in connection with the processing of agricultural products and the marketing of agricultural products);

b) Start-up aid for young farmers and for the development of small farms;

c) Aid for the transfer of agricultural holdings;

d) Start-up aid for producer groups and organizations in the agricultural sector; 
e) Aid for agri-environment-climate and animal welfare commitments (Aid for agri-environment-climate commitments, Aid for animal welfare commitments)

f) Aid for disadvantages related to Natura 2000 areas and to the Water Framework Directive;

g) Aid to areas facing natural or other specific constraints;

h) Aid for organic farming;

i) Aid for the participation of producers of agricultural products in quality schemes;

j) Aid for provision of technical support in the agricultural sector (Aid for knowledge transfer and information actions, Aid for advisory services, Aid for farm replacement services);

k) Aid for co-operation in the agricultural sector;

2. Risk and crisis management:

a) Aids to compensate for the damage to agricultural production or the means of agricultural production and to prevent damage (Aid to make good the damage caused by natural disasters or exceptional occurrences, Aid to compensate for damage caused by adverse climatic event which can be assimilated to a natural disaster, Aid for the costs of the prevention, control and eradication of animal diseases and plant pests and aid to make good the damage caused by animal diseases and plant pests, Aid for fallen stock, Aid to compensate for the damage caused by protected animals, Aid for the payment of insurance premiums, Aid for financial contributions to mutual funds);

b) Aid for Closing Production Capacity (Closing of capacity for animal, plant or human health, sanitary, ethical or environmental reasons, Closing of capacity for other reasons);

3. Other types of aid in the agricultural sector:

a) Aid to the livestock sector;

b) Aid for promotion measures in favour of agricultural products;

c) Aid for the outermost regions and the smaller Aegean islands;

d) Aid for agricultural land consolidation;

e) Aid for rescuing and restructuring undertakings in difficulty;

f) Aid for research and development in the agricultural sector.

4. Aids in rural areas which are co-financed by the EAFRD or granted as additional national financing to such co-financed measures:

a) Aid for investments concerning the processing of agricultural products into non-agricultural products, the production of cotton or investments in the creation and development of non-agricultural activities;

b) Aid for basic services and village renewal in rural areas;

c) Business start-up aid for non-agricultural activities in rural areas;

d) Aid for agri-environment-climate commitments to other land managers and undertakings in rural areas not active in the agricultural sector;

e) Aid for disadvantages related to Natura 2000 areas to other land managers;

f) Aid for knowledge transfer and information actions in rural areas;

g) Aid for advisory services in rural areas;

h) Aid for new participation of active farmers in quality schemes for cotton and foodstuffs;

i) Aid for information and promotion activities concerning cotton and foodstuffs covered by a quality scheme;

j) Aid for co-operation in rural areas;

k) Aid for setting-up of mutual funds [29].

As we already said, State aid must be notified to the Commission. After the procedure, the Commission may make several decisions: 1) There is no state aid in present case, 2) state aid is compatible with the internal market, 3) state aid is compatible with the internal market (condi- 
tional decision), and 4) state aid is incompatible with the internal market. The worst decision for Member State is the decision of incompatibility. In that case, the Commission may require the Member States to recover the illegal state aid. States are required to act on the orders of the Commission and will be able to refuse the order for recovery of aid only if they prove that it would be absolutely impossible. Therefore, in practice, member states try to avoid repayment assistance in different ways. In order to avoid a negative decision on state aid for rural development Member States may carry out preliminary consultation with the Commission, before granting state aid. This is not provided by EU competition law, but also did not prohibit. Therefore, it is common practice. This is the way to avoid potential disputes with the Commission [30].

\section{CONCLUSION}

One of the problems according to rural tourism is having no official data of the number and situation in rural areas as well as the lack of strategy of rural tourism development. The potential of new destinations and capacities is great, as well as labour forces, so if investors (both European and Serbian) and all the stakeholders of rural areas would invest in it, we could become a leading country in rural tourism supply in the region.

Also, one of the most delicate issues of the future development of the tourism in rural areas is the aging and education structure of the population in these areas. This problem is important both from the aspect of the social structure of rural environments, as well as the capacity of human resources for adopting new technologies, changing the socio-economic structure and many others. Therefore, addressing the issue of strengthening the social structure of rural communities is a huge imperative and contributes greatly to state aid for rural development.

Finally, it should not be ignored that the EU member states can provide state aid measures for rural development. Given that the provision of state aid is a priori inadmissible in the European Union, it is necessary to fulfill the requirements provided by the Treaty on the Functioning of the European Union, as well as the Guidelines for State aid in the agricultural and forestry sectors and in rural areas 2014 to 2020. To avoid any potential disputes between Member States and the European Commission, member states are recommended to carry out preliminary discussions with the Commission. In this way, the attitude of the Commission will be known in advance and the Member States will know how to formulate a proposal of state aid measures for rural development. Commission's decision on illegally granted state aid can be problematic for Member State. In that case, Member States would have to recover illegally granted state aid. Bearing that in mind, the practice of the Commission and the Court of Justice will be of great importance not only for the Member States of the European Union, but also for the candidate countries. 


\section{REFERENCES}

[1] Zhao et al. (2011) Social Capital and Tourism Entrepreneurship, Annals of Tourism Research, 38(4), pp. 1570-1593.

[2] Moscardo, Gianna (2014) Tourism and Community Leadership in Rural Regions: Linking Mobility, Entrepreneurship, Tourism Development and Community Well-Being, Tourism. Planning \& Development. 11(3), pp. 354-370.

[3] www.nbs.rs on 08.11.2018.

[4] https://ec.europa.eu/eurostat/statistics-explained/index.php/Enlargement_countries_-_labour_market_statistics\#Employment_rates

[5] Statistical Office of the Republic of Serbia. http://arhiva.stat.gov.rs/WebSite/Public/PageView.aspx?pKey=2, accessed 08.11.2018.

[6] https://ec.europa.eu/agriculture/sites/agriculture/files/bilateral-relations/pdf/serbia_en.pdf

[7] Government of The Republic of Serbia, The Strategy for Agriculture and Rural Development of the Republic of Serbia for the period 2014-2024, http://uap.gov.rs/wp-content/ uploads/2016/05/STRATEGIJA-2014-2020-.pdf pp. 42

[8] Government of The Republic of Serbia, The Tourism Development Strategy of the Republic of Serbia for the period from 2016 to 2025, Belgrade, 2018, http://mtt.gov.rs/download/3/strategija.pdf, pp. 28, 80, 97, 98 .

[9] http://srpskamagaza.com/doks/Odrzivi_Turizam_elektronsko_izdanje.pdf pp.39-42

[10] Government of The Republic of Serbia, The Tourism Development Strategy of the Republic of Serbia for the period from 2016 to 2025, Belgrade,2018, pp.97-98.

[11] Vukadinovic S., Employment as a factor of economic development of the Republic of Serbia, $\mathrm{PhD}$ thesis 2016, Faculty of business Economy, Educons University, Sremska Kamenica, Serbia, 2016, pg.1-290.

[12] https://www.agromedia.rs/Zivot-na-selu/seoski-turizam/srbija-zemlja-seoskog-turizma-i-srdacnih-domacina

[13] https://www.selo.rs/rs

[14] Domazet, Jotic, Jesic (2018) State aid for rural development in the European Union, Business economy, Educons University, no. 1/2018.

[15] Zahra, S. A. et al. (2008) Globalization of Social Entrepreneurship Opportunities. Strategic Entrepreneurship Journal, (2) pp. 117-131. Retrieved, April 15, 2015, from http://socialeconomyaz.org/wpcontent/uploads/2011/01/zahra.pdf

[16] Thompson, John L. (2002) „The World of the Social Entrepreneur”. International Journal of Public Sector Management, 15(5) pp. 412 - 431. Retrieved April 19, 2015 from http:// dx.doi.org/10.1108/09513550210435746

[17] Jiao, H. (2011) A Conceptual Model for Social Entrepreneurship Directed Toward Social Impact on Society. Social Enterprise Journal, 7(2), pp. 130-149.

[18] Djuran, J., (2012), Social entrepreneurship in the countries of the European Union and possibilities of social entrepreneurship in the Republic of Serbia, Business economy, Educons University, no. 1/2012, pp. 217-238.

[19] Iorio, M and Corsale. (2010). Rural tourism and livelihood strategies in Romania, Journal of Rural Studies 26(2), pp. 152-162.

[20] JICA Research Institute. (2015). Effective Approaches for Rural Development. Chapter 4. Retrieved from http://jicari.jica.go.jp/IFIC_and_JBICIStudies/english/publications/reports/study/topical /spd/pdf/chapter4.pdf.

[21] Mukhtar, M. (2009). The role of microfinance banks in the promotion and development of entrepreneurship in semi urban and rural areas. Retrieved from http://www.focusnigeria.com/ microfinance -banks.htm. 
[22] Jha, U. M and Jha, N. (2008). Economics of rural development, International Journal of Rural Studies 15(1), 1-20. Retrieved from www.ivcs.org.uk/IJRS.

[23] Osborne, S.P., Beattie, R.S. and Williamson, A.P. (2002) Community involvement in rural regeneration partnerships in the UK: evidence from England, Northern Ireland and Scotland, Policy Press, London.

[24] Kay, A. (2003) Social capital in building the social economy. In: J. Pearce (ed.), Social Enterprise in Anytown, Calouste Gulbenkian Foundation, London, pp.72-83.

[25] Budd, L. (2003) Can social enterprise succeed in building the regional agenda? Regions, 243(1), pp.7-11.

[26] Mandl, I., Oberholzner, T. and Dorflinger, C. (2007) Social Capital and Job Creation in Rural Europe, European Foundation for the Improvement of Living and Working Conditions, Dublin.

[27] http://www.rra-bp.rs/uploads/Prirucnik\%20LEADER\%20finalni.pdf pp. 6, 15.

[28] Guidelines for State aid in the agricultural and forestry sectors and in rural areas 2014 to 2020, OJ C 204, 1.7.2014, p. 1-97, 133-718.

[29] Domazet, S. (2015). State Aid for risk management and crisis in the agriculture sector in the European Union, Glasnik advokatske komore Vojvodine, 75(3-4) pp. 394,395.

[30] Domazet, S. (2013) Environmental protection and competition law in the European Union: complementary or conflicting goals? In: Agriculture in Serbia and Portugal: recent developments and economic implications, Coimbra, pp. 229-230. 